\title{
1978 Financial Statement of the International Union of Geological Sciences
}

(See Note 1)

Statement of Receipts and Payments For the Year Ended December 31, 1978

RECEIPTS

- IGCP contracts from UNESCO (See Note 2)

- Membership fees (See Note 3)

- Subvention from UNESCO via ICSU (See Note 4)

- Reimbursements (See Note 5)

- Sales: EPISODES (1978)

Geological Newsletter (in 1977 only)

Advertising in EPISODES

- Canadian Government Contribution to IUGS Secretariat

- Interest

- Subvention from UNESCO for IUGS/ ICG/IGCP display

- Royalties from Wiley's for Stratigraphic Guide

- Tax refund

- Other contracts: UNESCO (See Note 6)

- Subvention for COGEODATA (See Note 7)

Currency adjustment (See Note 8)
Graz Treasury (See Note 9)

Ottawa Secretariat

Production of newsletters:

Geological Newsletter (back payment for 2 issues in 1977)

EPISODES ( 4 issues in 1978)

- Executive Committee meeting

- Inter-Union Commission on Geodynamics (see Note 4)

IUGS officers' travel costs

Affiliated Associations (See Schedule B)

- IUGS support for IGCP projects

- Transfer of files from Haarlem to Ottawa

IUGS display/promotion/public relations

- Bank charges

- ICSU subvention (See Note 4)
1978

(\$U.S.)

109550

94131

12000

7621

6345

1149

3400

2411

500

131

58

52

15610

TOTAL

252958

118068

22387

16868

4266

1977

(\$U.S.)

114560

89513

12000

6912

4555

1249

300

229089

229089

14184

11266

15660

12000

7897

5600

6525

1640

1173

992

360

238886

Exchange

TOTAL

238886
122533

27960

24631

12926

12379

8000

3315

5541

4107

952

4490

226834

1166

228000

\section{STATUS OF ACCOUNTS}

Excess $(+)$ or Deficit (-) of receipts to payments

Bank balances, end of year (See Schedule C)

Accounts receivable as of December 31,1978

Accounts payable as of December 31, 1978

Net financial assets as of December 31, 1978

$+1089$

77836

78925 
NOTES TO THE 1978 FINANCIAL STATEMENT

Note 1

The statement of Receipts and Puyments and the Statement of Bank: Balances of the IUG for the year ended nerember. 1978, have been prepared by the Treasurer in acrordance with the Statutes and lyye-laws of the tnion. Receipts and payments have been recorded in the books of arcount in the currency of the bank aredint lised, and then ronverted to \$U.S. at ycar-end based on official lCSU rates of exchange for Deccmber 31, 1978

The Statements do not reflect:

i) the costs borne by member countries in support of activities and operations of the Union:

b) ariy unpaid accounts receivabie or payable by the

Union as at Dercmber $31,1978$.

Note 2

IGCP receipts rone from one soure: contract funds from ENESCO atlorited to ICG (P' projects. Total payments to iGCP projerts. however, include the following: the contract funds from liNESCO, an anntal contribution from ILGS of $\$ 10000$ and the IIGG.S advances paid to projects to cover and financial statements are suburited by $11, \mathrm{GS}$.

Note 3

This includes $\$ 6.25 \%$ paid in 1978 for 1977 member ship fees Yember countries pay amoual contributions atcrording to their sele ted rategory of mermberstip as outlined in the fol weing tabs:

$\begin{array}{lllllllll}\text { Category } & 1 & 2 & 3 & 4 & 5 & 6 & 7 & 8\end{array}$ $\begin{array}{lllllllll}\text { vinits. of } & 1 & 2 & 4 & 6 & 10 & 13 & 25 & 50\end{array}$ Contribution

(-One unit of contribution is atrrently valued at $11.5 . \$ 200$. Membership fees remain fixed for four years.

\section{Note 4}

1IGS receives $\$ 12000$ from ICST as an upportioned arnount of the TNESCO subvention to ICSIJ. RIGGS Days a fixed anntal contribution of $\$ 10000$ to ICG (in 1977 only $\$ 8000$ was paid. $\$$ ? 000 was paid carly in 1978) and an annual subvention to ICSU based on $2.5 \%$ of ILGS mernbership lees. Full payment for 1978 wals not made by $31 / 64$ : until 1979 ).

Note 5

This inc -udes repayments of funds for IGCP propects, not needed or to be redirested; refund from IIICS/Prague; repulyment of expenses from ICSUl; and miscellaneous receipts.

Note 6

Final payments on UNESCO Contract No. 550.567 for inceting of Committec on Geology Teaching and Contrart No. 550.853 for coceonata conference.

Note 7

Subvention for COGEODATA paid by the Netherlands.

Note 8

This includes $\$ 13652$ increase during 1978 in dollar vatue of funds in Zurich account at end of ycur, plus $\$ 1987$ inof funds in Zurich account at end of year, plus $\$ 1987$ in-
crease during 1978 in dollar value of funds transferced from crease during 1978 in dollar value of funds trancherred fro
Zurich to Graz arcount in mid-year, minus $\$ 29.00$ loss in zurkeh to Graz account in mid-year, minus $\$ 29.00$ loss in
dollar vilue through exchange of funds transterred to Hatarlem.

\section{Note 9}

This includes $\$ 3051$ in tax paynents for 1977 and 1975

Note 10

This includes representation to COSPAR.

Note 11

1978 contribution to IAcion fone of the three constitucnt societies of JFSEG

Note 12

From 22 countries.

Note 13

For 27 IGeP projects: $\$ 5700$ from 21 projects had beel repaid as of February 3, 1979
SCHEDULE A

1978 PAYMENTS: UUGS COMMISSIONS AND COMMITTEES

\begin{tabular}{|c|c|c|}
\hline & 1978 & 1977 \\
\hline Murine Geology & I 437 & 2400 \\
\hline \multicolumn{3}{|l|}{ Stratigraphy: } \\
\hline Sverall Commission & 2010 & 1300 \\
\hline \multicolumn{3}{|l|}{ Subcommissions: } \\
\hline Precambrian/Cambrian Bdy & 1550 & $\begin{array}{r}2500 \\
200\end{array}$ \\
\hline Cambrian/Ordovirian Bdy & 1100 & 100 \\
\hline Ordovician/Silurian Bdy & 100 & \\
\hline Silurian & 415 & 1700 \\
\hline Devonian & 1500 & 200 \\
\hline Devonian/Carb. Fidy & 100 & 1500 \\
\hline Carbonferous & 555 & 575 \\
\hline Jurnssic & 450 & 400 \\
\hline Cretion cous & 800 & 1800 \\
\hline Paleogene & 350 & 400 \\
\hline Palcogene/Ncogene $B_{d y}$ & 300 & 200 \\
\hline Mediterranean Neogene & 550 & 100 \\
\hline Quaternatry & 1300 & \\
\hline Stratigraphical Lexicon & 600 & 600 \\
\hline Stratigraphic Classification & 1000 & \\
\hline Magnetic Polarity Time Scale & 475 & 1500 \\
\hline \multicolumn{3}{|l|}{ Systematies in Petrology } \\
\hline Experimental Petrology & 2000 & 1200 \\
\hline Terionies & & 1800 \\
\hline Geology Tearhing & & 985 \\
\hline Dorumentation & 800 & 1800 \\
\hline COGEONATA & 4000 & 2400 \\
\hline INHKIEO & 750 & 400 \\
\hline Advisory Board for Publication & 250 & \\
\hline \multicolumn{3}{|l|}{ Internationat Lexicon } \\
\hline TOTAL & 22387 & 27960 \\
\hline
\end{tabular}

SCHEDULE B

1978 PAYMENTS: IUGS AFFILIATED ASSOCIATIONS

Commission for the Geologiral

Map of the world (CCimw)

European Assoriation of Earth

Srimre Editors (EDITERR

Engancer Association of
Engeology (IAEG)

Intermitional Association of

Hydrogeologists (IAH)

Mathematical Geology (LAMG)

Mathematical Geology

mernational Assoriation of
Panetology (MAP) (See Note 10$)$

International Federation of Societies

of Ficonomic cieologists (IFSEG)

of Fironomic (sec Note 11)

Intermational Inion for Quaternar

Rescarch (INOUA)

Intemational Patacontologicat

Assoriation (IPN)

\begin{tabular}{rr}
2000 & 2000 \\
300 & 541 \\
300 & 500 \\
300 & 500 \\
300 & 500 \\
800 & \\
1000 & 500 \\
300 & 500 \\
300 & 500 \\
\hline 5600 & 5541 \\
\hline
\end{tabular}

\section{SCHEDULE C:}

STATUS OF IUGS ACCOUNTS

$$
\text { Derember } 31,1978
$$

Bank Balances

$$
\begin{aligned}
& \text { Ciraz (dollar arcount) } \\
& \text { (mirk account) }
\end{aligned}
$$

TorAl

(\$D.S.)

37718

568

118

49453

419
399

399

1845

Add: Accounts Receivable

Mornbership Fees (Soe Note 12)

kiCP Project Refunds (See Note

Other reimbursements

TOTAL

6000

ess: Accounts Payable

ICSUl payment at $2.5 \%$ or mem-

bership lees for $1977 \& 1978$

IGCP Project advances

Repayment of part of $11 \mathrm{lGS}$ -

UNESCO rontract 550.280 for

Gice Project 26

TOTAL

\section{BUDGET FOR 1979}

(\$SU.S.)

Approved by the UUGS Exerutive Committed zurich, February 10,1979

Anticipated Revenues*

(\$1j.5.)

Membership fees (ideal $\$ 96000$ ); probable

Subvention from IC SIJ

EPISOIES: Subscription

Advertising
Adion

Interest on bank arcounts

TOTAL

90000

12000

7500

2000
750

112250

Anticipated Expenditures* *

Scientific Program

International Geological

$$
\text { Correlation Programme }
$$

10000

Drogramme 10000

IUC.S Commissions

Stratigraphy $\quad 14000$

Marine Geology (See Note A below)

Systernatics in Petrology

Experimental Petrology

IUGS Committees

COGEODATA (See Note B below)

Geology Teacting

Geologicul nocumentation

Advisory hourd for Publication

IUGS Affiliated Assoriations

Commission for the Geological Map of the World (CGMW)

International Association of
Engineering Geology (IAEG)

International Association of
Mathematical Coology (1AMC)

Nathematical Ceology (1 A.MC

International Association of

Internutional Association of

Hydrogeologists (IAH)

international Union for Quaternary
Rescarch (INQUA)

European Association of Earth

Srience Editors (EDITERRA)

international Federation of Societies
of Eronomic Gcologists (IFSEC)

IIJG.5 Geodynamics Symposium, Zurirh, 1979

Contingency fund for allocation by Secretary General

\section{Sub-Total}

2000

1000

600

500

500

500

300

300

8970

2500

Organizational Activitics

Secretariat Operations

Ottawa

Zurich

Washi

Grat

Printing, publication and distribution

Executive Committce Mceting, Zurich, 197

UUG.S Subventions and other contributions

it:Gs representation

\begin{tabular}{lr} 
Sub-Total & 2000 \\
TOTAL & 55400 \\
\hline 119620
\end{tabular}

Budgeted excess of expenditures over revenues

* Does not include accounts reccivable listed in schedule $C$.

* * Does not include arcounts payable listed in Schedule $\mathrm{C}$

Note A.

4591 Funds that berome avalable in andition to these atloFations will be given, as a firct priority. to Marine $\mathrm{CoO}_{-}$ ogy.

Note B.

An additional allocation of $\$ 4000$ may be made to $\mathrm{CO}$ Net Financial Assets 101917 

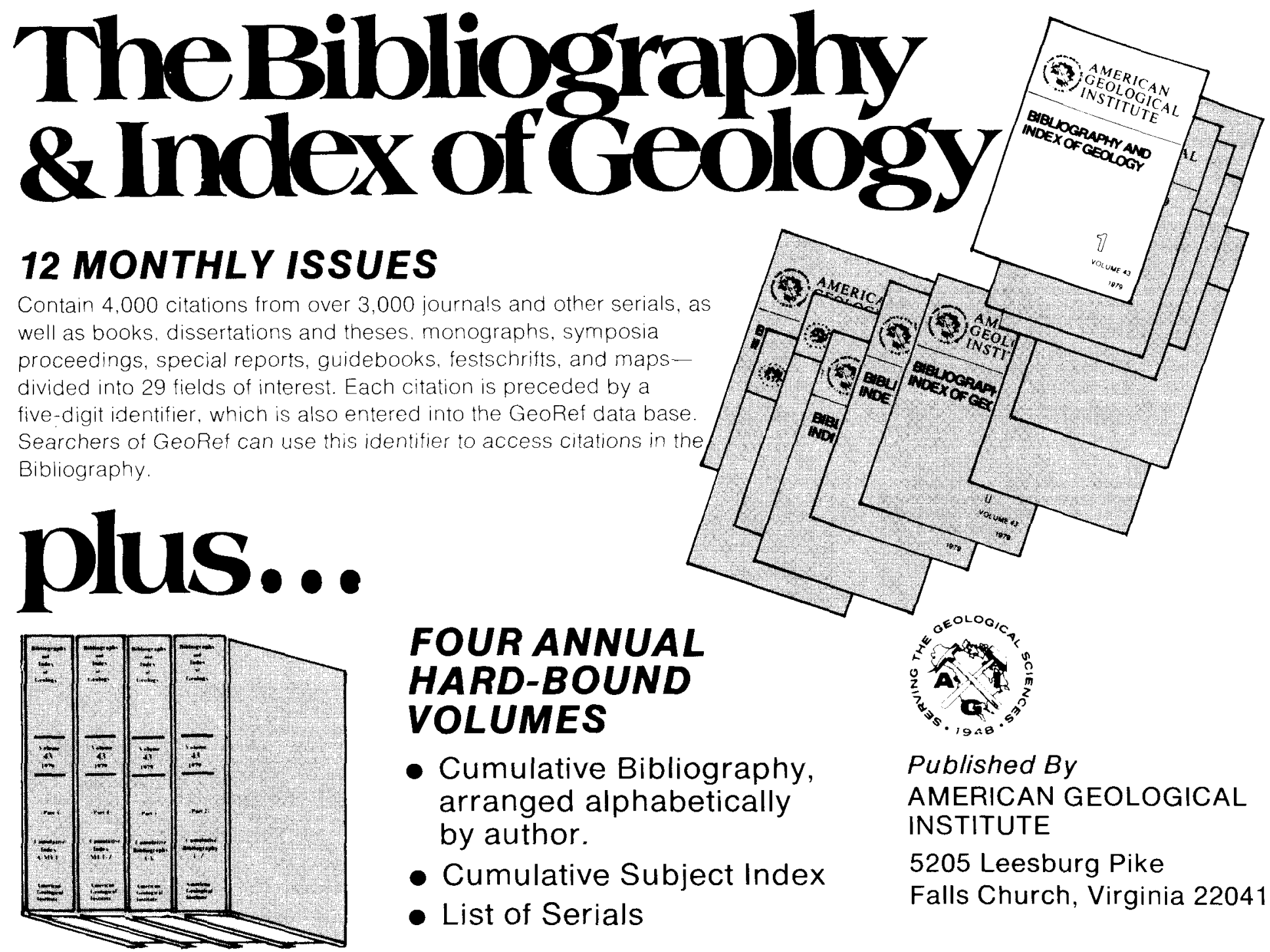

\section{FOUR ANNUAL HARD-BOUND VOLUMES}

- Cumulative Bibliography, arranged alphabetically by author.

- Cumulative Subject Index

- List of Serials

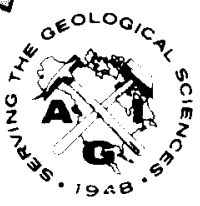

Published By

AMERICAN GEOLOGICAL INSTITUTE

5205 Leesburg Pike

Falls Church, Virginia 22041

\section{THESE SUPPLEMENTAL AIDS ALSO AVAILABLE}

*GeoRef Serials List and $K W O C$ Index, 1978. 13 fiche set, $29 X$

Covers over 5000 serials cited in the BIBLIOGRAPHY AND INDEX OF GEOLOGY from 1967 to June 1978. The Serials List is arranged alphabetically by full title (4 fiche). The Key Word Out of Context (KWOC) Index contains each significant word in the serial titles. has a complete STOP LIST ( 9 fiche).

Use coupon \& mail today!
GeoRef Thesaurus and Guide to Indexing, 2nd edition

A cross-referenced list of all terms in GeoRef, with usage notes, and structured lists of terms. 456 pp., over 12,000 terms. Available printed or on microfiche

American Geological Institute Publications Department 5205 Leesburg Pike Falls Church, Virginia 22041 Gentlemen:

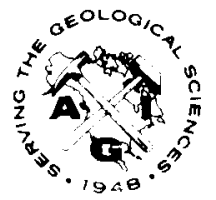

$\square$ Please enter ___ subscription(S) to the Bibliography and Index of Geology, (a) $\$ 750$ USA, $\$ 765$ non-USA

$\square$ Please send _.... set(s) of GeoRef Serials List and KWOC Index,@\$15 per set.

$\square$ Please send GeoRef Thesaurus and Guide to Indexing, _....... copies printed, (a) \$35 per copy: _ copies on microfiche, @ \$20 per copy.

$\square$ i enclose \$ (US\$ or UNESCO coupons)

$\square$ Invoice needed: Purchase Order No.

$\square$ AGI Publications List Requested

Ship to: Name 